\title{
PERAN MIKORIZA PADA SEMAI BEBERAPA SUMBER BENIH MANGIUM (Acacia mangium Willd.) YANG TUMBUH PADA TANAH KERING
}

The role of micorrhizal in seedling of Mangium (Acacia mangium Willd.) from some seed sources in soil drought

\author{
Nur Hidayati ${ }^{1}$, Eny Faridah ${ }^{2}$ dan Sumardi ${ }^{2}$ \\ ${ }^{1}$ Balai Besar Penelitian Bioteknologi dan Pemuliaan Tanaman Hutan, \\ Jl. Palagan Tentara Pelajar Km. 15, Purwobinangun, Pakem, Sleman, Yogyakarta, Indonesia \\ e-mail: inunghidayati@yahoo.com \\ ${ }^{2}$ Fakultas Kehutanan, Universitas Gadjah Mada \\ Jl. Agro No. 1, Bulaksumur, Sleman, Yogyakarta, Indonesia
}

Tanggal diterima : 9 Februari 2015, Tanggal direvisi : 23 Februari 2015, Disetujui terbit : 30 April 2015

\begin{abstract}
Plants that have mycorrhizal symbiosis tend to be more resistant to the drought because external hyphae of mycorrhizal will expand the surface of water uptake and it can infiltrate into capillary pores so that water uptake for the host plant need will increase. This study aimed to know the response and adaptation mechanisms of mangium in facing drought stress, to investigate mycorrhizal roles in overcoming drought stress on mangium, and to select the origin of mangium seed source that is tolerant to drought stress. The study used mangium seedlings from four different seed sources and was arranged in split plot pattern of randomized block design, with three factors. The result showed that mangium root infected by mycorrhizal decreased along with increasing level of watering intervals. Mycorrhiza increased height-diameter growth and total biomass of mangium for the entire seed source. Total biomass growth of seven month mangium was significantly influenced by the origin of seed source. The highest total biomass was derived from F-1 Wonogiri (7.14 grams) and followed by Group B (6.82 grams), Group C (6.21 g) and Group A (5.84 g). Adaptation mechanisms of mangium seedlings during drought stress were keeping the water status of the plant, improving plant roots system, and thickening the leaf blades.
\end{abstract}

Keywords: Mangium, Acacia mangium, mycorrhizal, watering interval, seed source

\begin{abstract}
ABSTRAK
Tanaman yang bersimbiosis dengan mikoriza cenderung lebih tahan terhadap kekeringan karena jaringan hifa eksternal mikoriza mampu menyusup ke pori kapiler sehingga serapan air untuk kebutuhan tanaman inang akan meningkat. Penelitian ini bertujuan mengetahui respon dan mekanisme adaptasi tanaman Mangium (Acacia mangium) dalam menghadapi cekaman kekeringan, peran mikoriza dalam mengatasi cekaman kekeringan pada Mangium serta asal sumber benih tanaman Mangium yang toleran terhadap cekaman kekeringan. Penelitian ini menggunakan materi berupa bibit tanaman Mangium yang berasal dari 4 sumber benih yang berbeda dengan menggunakan rancangan acak kelompok dengan pola petak terbagi (split plot design) dengan tiga faktor. Hasil penelitian menunjukan bahwa Infeksi akar Mangium oleh mikoriza mengalami penurunan seiring dengan semakin lamanya interval penyiraman. Mikoriza meningkatkan pertumbuhan tinggi, diameter dan biomassa total tanaman Mangium dari semua sumber benih. Pertumbuhan biomassa total Mangium umur 7 bulan dipengaruhi secara nyata oleh sumber benih. Biomassa total tertinggi berasal dari F-1 Wonogiri (7,14 gram), Grup B (6,82 gram), Grup C (6,21 gram) dan Grup A (5,84 gram). Mekanisme adaptasi bibit Mangium terhadap cekaman kekeringan yaitu dengan menjaga status air jaringan, perkembangan perakaran tanaman dan penebalan helaian daun.
\end{abstract}

Kata kunci: Mangium, Acacia mangium, mikoriza, interval penyiraman, sumber benih 


\section{PENDAHULUAN}

Acacia mangium Willd. yang selanjutnya disebut Mangium merupakan salah satu tanaman yang potensial untuk merehabilitasi lahan-lahan kritis. Lahan kritis didefinisikan sebagai lahan yang mengalami proses kerusakan fisik, kimia dan biologi karena tidak sesuai penggunaan dan kemampuannya, yang akhirnya membahayakan fungsi hidrologis, orologis, produksi pertanian, pemukiman dan kehidupan sosial ekonomi serta lingkungan. Kekeringan dan terbatasnya ketersediaan unsur hara bagi tanaman merupakan salah satu masalah yang dihadapi dalam upaya rehabilitasi lahan kritis. Kendala pokok pembudidayaan lahan kering ini adalah keterbatasan air, baik itu curah hujan maupun air aliran permukaan.

Cekaman kekeringan merupakan istilah untuk menyatakan bahwa tanaman mengalami kekurangan air akibat keterbatasan air dari lingkungannya yaitu media tanam. Menurut Levitt (1980) dan Bray (1997) cekaman kekeringan pada tanaman dapat disebabkan kekurangan pasokan air di daerah perakaran dan permintaan air yang berlebihan oleh daun akibat laju evapotranspirasi melebihi laju absorpsi air walaupun keadaan air tanah tersedia cukup. Cekaman kekeringan akan berpengaruh terhadap pertumbuhan dan perkembangan tanaman yang mencakup aspek morfologi dan anatomi, fisiologi dan biokimia tanaman.

Mikoriza merupakan suatu bentuk simbiosis mutualistik antara jamur dan akar tanaman (Brundrett et al., 1996). Tanaman bermikoriza cenderung lebih tahan terhadap kekeringan dibandingkan dengan tanaman yang tidak bermikoriza. Pada tanaman yang bermikoriza, reaksi tanaman yang mengalami cekaman kekeringan cenderung lebih tahan terhadap kerusakan jaringan korteks dibanding tanaman tanpa mikoriza. Penelitian ini bertujuan untuk mengetahui reaksi dan mekanisme adaptasi tanaman Mangium dalam menghadapi kekeringan, peran mikoriza dalam mengatasi kekeringan serta asal sumber benih tanaman Mangium yang toleran terhadap kekeringan.

\section{BAHAN DAN METODE}

Bahan yang digunakan dalam penelitian ini adalah benih yang berasal dari 4 kelompok sumber benih Mangium yaitu Kebun Benih Semai Uji Keturunan Generasi Pertama (F-1) Wonogiri Jawa Tengah selanjutnya disebut F-1 Wonogiri, Kebun Benih Semai Uji Keturunan Generasi Kedua (F-2) Grup A selanjutnya disebut Grup A, Kebun Benih Semai Uji Keturunan Generasi Kedua (F-2) Grup B selanjutnya disebut Grup B, Kebun Benih Semai Uji Keturunan Generasi Kedua (F2) Grup $C$ selanjutnya disebut Grup $C$. 
Grup A dan Grup C berasal dari PT Inhutani II Pulau Laut Kalimantan Selatan dan Grup B berasal dari PT Inhutani III Pelaihari, Kalimantan Selatan. Mikoriza yang digunakan dalam penelitian ini merupakan vasicular arbuskular mikoriza, yang merupakan campuran jenis Glomus sp. dan Gigaspora sp.

Penelitian ini meliputi beberapa tahap kegiatan yaitu :

\section{A. Persemaian benih Mangium}

Tanah permukaan (top soil) yang berasal dari hutan penelitian Mangium di Wonogiri Jawa Tengah disterilkan dengan cara dijemur di atas lembaran seng sampai kering. Hari pertama tanah dijemur di atas lembaran seng yang dibiarkan dalam kondisi terbuka kemudian hari kedua tanah dibasahi dengan air secara merata untuk menumbuhkan spora jamur yang masih ada kemudian tanah ditutup dengan seng dan dijemur di bawah sinar matahari. Demikian secara berulang selama beberapa hari sampai tanah benar-benar kering. Selanjutnya tanah yang telah steril ini dimasukkan dalam polybag masingmasing sebanyak 1,3 kg per polybag. Setelah media tanam siap kemudian semai dari bak tabur dipindahkan ke dalam polybag. Kemudian bibit dipelihara dalam persemaian hingga berumur 3 bulan di dalam rumah kaca dengan melakukan penyiraman, pembersihan gulma serta pemeliharaan dari hama dan penyakit.

\section{B. Penetapan kapasitas lapang}

Penetapan kadar air kapasitas lapang $\quad(\mathrm{pF}$ 2,54) dianalisis oleh laboratorium tanah, Balai Pengkajian Teknologi pertanian, Kementerian Pertanian. Penetapan kadar air kapasitas lapang ini dilakukan untuk menentukan jumlah air yang diberikan pada masingmasing tanaman pada waktu penyiraman. Jumlah air yang diberikan (gram) :

Jumlah air pada kapasitas lapang (\%) X jumlah tanah per polybag (gram)

\section{Inokulasi jamur mikoriza}

Inokulasi dilakukan bersamaan dengan penyapihan semai ke dalam polybag. Setiap polybag diberi 30 gram jamur mikoriza ( \pm 90 spora $)$ dan dibenamkan di dalam tanah di dekat akar.

\section{Penentuan perlakuan cekaman kekeringan}

Hasil penetapan kapasitas lapang tanah yang digunakan sebesar 39,2\%. Perlakuan cekaman kekeringan diberikan melalui pengaturan interval penyiraman setelah media tanam dalam keadaan kapasitas lapang (509,6 ml). Penyiraman semai dilakukan sebanyak 509,6 $\mathrm{ml}$ dengan interval waktu yang berbeda-beda sesuai perlakuan :

- Interval penyiraman setiap 3 hari (H0)

- Interval penyiraman setiap 6 hari (H1) 
- Interval penyiraman setiap 9 hari (H2)

- Interval penyiraman setiap 12 hari (H3)

\section{E. Pengamatan dan pengukuran}

Pengamatan dilakukan menjelang dimulainya perlakuan cekaman kekeringan yaitu setelah bibit berumur 4 bulan sampai bibit berumur 7 bulan. Parameter yang diamati dan diukur adalah infeksi akar Mangium oleh mikoriza, tinggi semai, diameter, biomassa total, kadar air relatif daun, luas daun khusus dan nisbah pucuk akar.

\section{F. Rancangan penelitian}

Penelitian ini menggunakan rancangan acak kelompok dengan pola petak terbagi (split plot) menggunakan 3 faktor, meliputi faktor pertama sebagai faktor utama adalah tanpa inokulasi mikoriza (MO) dan inokulasi mikoriza (MI). Faktor kedua sebagai anak petak adalah perlakuan cekaman kekeringan yang terdiri dari 4 taraf yaitu interval penyiraman setiap 3, 6, 9 dan 12 hari. Faktor ketiga sebagai anak petak dari faktor kedua adalah sumber benih yang terdiri dari 4 kelompok sumber benih F-1 Wonogiri, Grup A, Grup B dan Grup C. Dengan demikian diperoleh 32 kombinasi perlakuan dengan 5 ulangan, masingmasing unit percobaan terdiri dari 1 tanaman sehingga diperoleh 160 unit percobaan.

\section{G. Analisis kandungan unsur hara pada daun}

Daun dari semai tanaman Mangium pada akhir penelitian dianalisis kandungan unsur hara N, P dan K-nya.

\section{H. Analisis data}

Data hasil pengamatan dianalisis dengan menggunakan analisa statistik pada taraf kepercayaan 95\% dan 99\%. Apabila hasil analisis menunjukkan perbedaan yang nyata, maka dilanjutkan dengan uji jarak berganda Duncan (Duncan's Multiple Range Test-DMRT).

\section{HASIL DAN PEMBAHASAN}

\section{A. Infeksi mikoriza terhadap akar mangium}

Kekeringan dapat memberikan pengaruh peningkatan atau penurunan derajat infeksi akar tanaman oleh vasicular arbuscular mikoriza (Auge, 2001). Hasil analisis statistik menunjukkan bahwa perlakuan mikoriza, sumber benih dan interval penyiraman berpengaruh sangat nyata terhadap persentase infeksi mikoriza pada akar semai Mangium (Tabel 1). Interaksi antara mikoriza dan sumber benih serta mikoriza dan perlakuan interval penyiraman juga berpengaruh secara nyata terhadap persentase infeksi mikoriza terhadap semai Mangium.

Perlakuan interval penyiraman yang semakin lama pada semai Mangium yang telah diinokulasi VAM cenderung 
menurunkan infeksi mikoriza terhadap akar Mangium. Akan tetapi, secara umum persentase infeksi mikoriza tergolong tinggi pada semua perlakuan interval penyiraman. Kriteria derajat infeksi VAM tergolong tinggi jika persen akar yang terinfeksi lebih besar dari 30\% (O’Connor et al., 2001).

Infeksi yang terjadi pada akar Mangium berupa hifa dan atau vesikel dalam jaringan korteks akar semai Mangium tersebut (Gambar 2). Hifa internal terdapat di antara sel-sel korteks akar dan bercabang-cabang di dalamnya, tetapi tidak sampai masuk ke dalam jaringan silinder pusat (Moose, 1981). Vesikel terbentuk melalui penggelembungan hifa internal, kebanyakan berbentuk bulat telur dan berisi banyak lipida sehingga dapat berfungsi sebagai cadangan makanan atau berkembang menjadi klamidospora, yang berfungsi sebagai organ reproduksi atau struktur tahan (Suhardi, 1989). Pada penelitian ini tidak ditemukan adanya arbuskula pada penampang akar yang terinfeksi mikoriza. Adapun kemungkinan tidak ditemukannya arbuskula pada saat pengamatan adalah siklus arbuskula yang sangat singkat yakni berkisar antara 4 sampai 15 hari, bahkan pada tanaman tertentu hanya 2 sampai 5 hari (Cooke et al., 1993).

Penurunan infeksi akar karena perlakuan interval penyiraman ini diduga karena jamur mikoriza lebih banyak membentuk spora dorman. Gunawan (1993) melaporkan pada saat tanah dalam kondisi kadar air yang rendah dapat ditemukan jumlah spora yang lebih banyak dibandingkan pada saat musim hujan. Adapun mekanismenya adalah pada saat musim kemarau, untuk mengatasi lingkungan yang kering, VAM akan membentuk spora untuk bertahan hidup, sedangkan di saat musim hujan dengan ketersediaan air yang banyak akan merangsang spora untuk segera berkecambah.

Tabel 1. Persentase infeksi mikoriza pada akar semai Mangium umur 7 bulan

\begin{tabular}{lc}
\hline \multicolumn{1}{c}{ Perlakuan } & Rata-rata persentase infeksi mikoriza (\%) \\
\hline Inokulasi mikoriza & $73,50 \mathrm{a}$ \\
Tanpa inokulasi mikoriza & $0 \quad \mathrm{~b}$ \\
\hline Rata-rata Grup B & $81,00 \mathrm{a}$ \\
Rata-rata F-1 Wonogiri & $77,50 \mathrm{ab}$ \\
Rata-rata Grup C & $70,00 \mathrm{bc}$ \\
Rata-rata Grup A & $65,50 \mathrm{c}$ \\
\hline Rata-rata interval penyiraman setiap 3 hari & $80,50 \mathrm{a}$ \\
Rata-rata interval penyiraman setiap 6 hari & $76,50 \mathrm{ab}$ \\
Rata-rata interval penyiraman setiap 9 hari & $70,00 \mathrm{bc}$ \\
Rata-rata interval penyiraman setiap 12 hari & $67,00 \mathrm{c}$ \\
\hline
\end{tabular}

Keterangan : Angka-angka yang diikuti oleh satu atau lebih huruf yang sama berarti tidak berbeda nyata pada taraf kepercayaan 95\% (DMRT) 


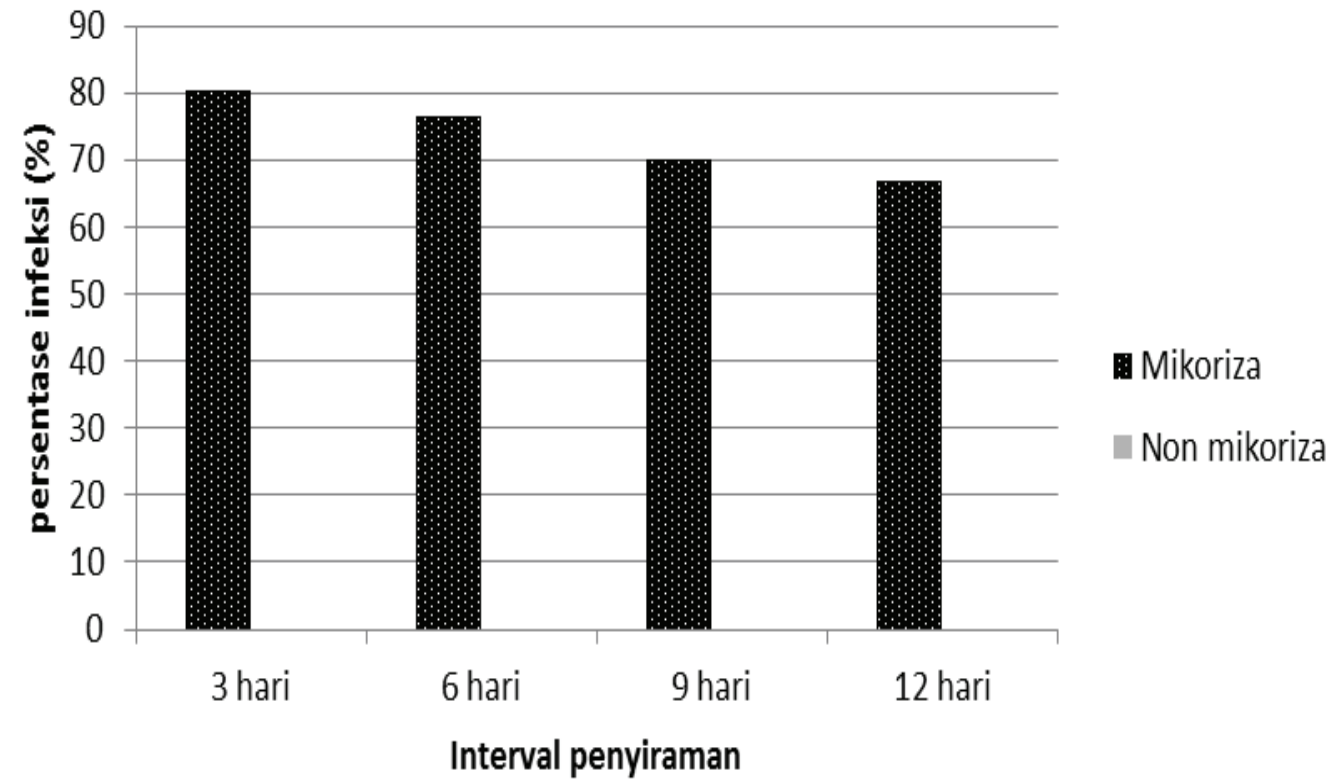

Gambar 1. Perbandingan rata-rata persentase infeksi mikoriza pada berbagai taraf perlakuan interval penyiraman
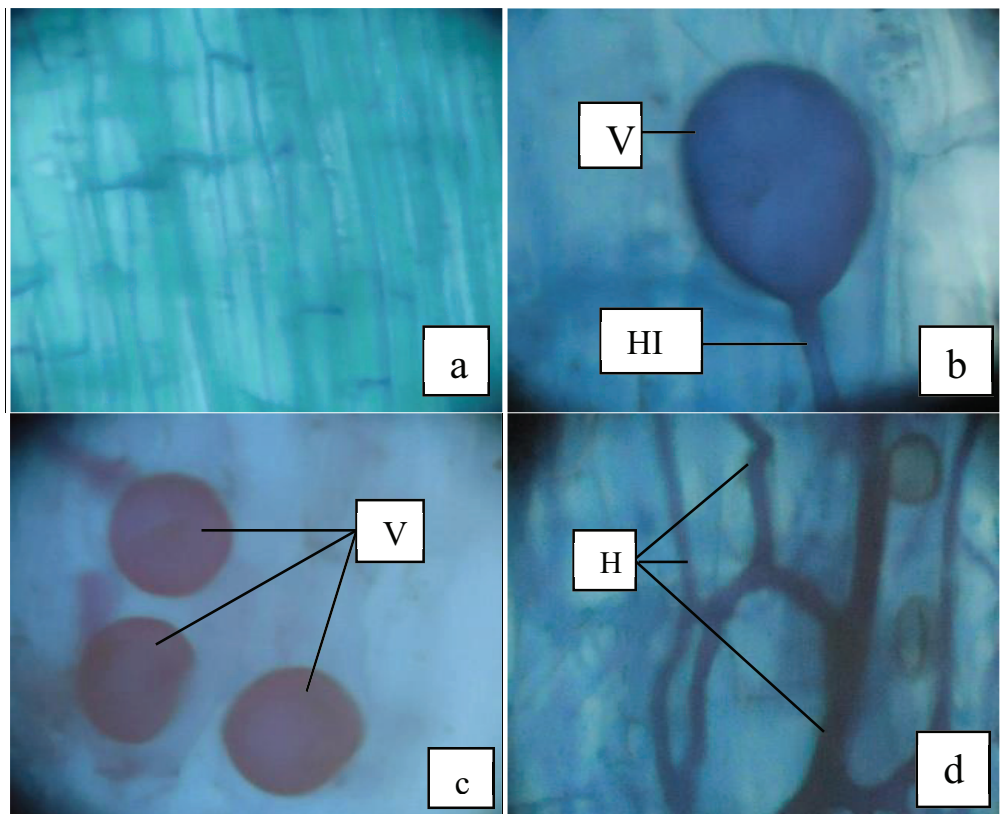

Gambar 2. Penampang akar semai Mangium (a). Penampang akar Mangium tanpa infeksi mikoriza (perbesaran 20x) (b.) Vesikel (V) mikoriza yang merupakan penggelembungan hifa internal (HI) (perbesaran 40x) (c.) Vesikel mikoriza tanpa hifa internal (perbesaran 40x) (d.) Hifa (H) (perbesaran 40x)

\section{B. Pertumbuhan semai Mangium}

Pertumbuhan tanaman dapat dilihat dari beberapa variabel, diantaranya adalah tinggi, diameter dan biomassa total tanaman. Pertumbuhan tanaman pada kondisi kekurangan air merupakan tanda suatu adaptasi tanaman terhadap cekaman kekeringan. 


\section{Pertumbuhan tinggi}

Hasil analisis statistik

menunjukkan bahwa perlakuan

mikoriza dan perlakuan interval

penyiraman

mempengaruhi

pertumbuhan tinggi semai Mangium,

sedangkan faktor sumber benih tidak mempengaruhi pertumbuhan tinggi semai. Interaksi antara masing-masing sumber variasi juga tidak mempengaruhi pertumbuhan tinggi semai Mangium.

Pemberian mikoriza menyebabkan pertumbuhan tinggi semai
Mangium semakin meningkat dibandingkan semai tanpa inokulasi mikoriza, tetapi menurun pada perlakuan penyiraman setiap 12 hari (Tabel 2). Hal ini diduga disebabkan karena kadar air yang lebih rendah pada perlakuan interval penyiraman setiap 12 hari, menyebabkan menurunnya infeksi mikoriza pada akar semai sehingga akan menurunkan pula peran mikoriza pada semai Mangium yang pada akhirnya akan menurunkan pertumbuhan tinggi tanaman.

Tabel 2. Rata-rata pertumbuhan tinggi, diameter dan biomassa total semai Mangium umur 7 bulan dari 4 sumber benih terhadap perlakuan mikoriza dan interval penyiraman (hari)

\begin{tabular}{lcclc}
\hline \multicolumn{1}{c}{ Perlakuan } & $\begin{array}{c}\text { Tinggi } \\
(\mathbf{c m})\end{array}$ & $\begin{array}{c}\text { Diameter } \\
(\mathbf{c m})\end{array}$ & \multicolumn{1}{c}{ Perlakuan } & $\begin{array}{c}\text { Biomassa } \\
\text { (gram) }\end{array}$ \\
\hline Inokulasi mikoriza & $18,98 \mathrm{a}$ & 0,16 & Inokulasi mikoriza & $7,89 \mathrm{a}$ \\
Tanpa inokulasi mikoriza & $15,77 \mathrm{~b}$ & 0,15 & Tanpa inokulasi mikoriza & $5,11 \mathrm{~b}$ \\
\hline Grup A & 16,03 & 0,16 & F-1 Wonogiri & $7,14 \mathrm{a}$ \\
Grup B & 17,21 & 0,17 & Grup B & $6,82 \mathrm{~b}$ \\
Grup C & 17,40 & 0,15 & Grup C & $6,21 \mathrm{~b}$ \\
F-1 Wonogiri & 18,85 & 0,15 & Grup A & $5,84 \mathrm{~b}$ \\
\hline Penyiraman setiap 3 hari & $29,95 \mathrm{a}$ & $0,25 \mathrm{a}$ & Penyiraman setiap 3 hari & $10,77 \mathrm{a}$ \\
Penyiraman setiap 6 hari & $15,08 \mathrm{~b}$ & $0,15 \mathrm{~b}$ & Penyiraman setiap 6 hari & $7,67 \mathrm{~b}$ \\
Penyiraman setiap 9 hari & $13,29 \mathrm{bc}$ & $0,12 \mathrm{c}$ & Penyiraman setiap 9 hari & $4,66 \mathrm{c}$ \\
Penyiraman setiap 12 hari & $11,17 \mathrm{c}$ & $0,11 \mathrm{c}$ & Penyiraman setiap12 hari & $2,89 \mathrm{~d}$ \\
\hline
\end{tabular}

Keterangan : Angka-angka yang diikuti oleh satu atau lebih huruf yang sama berarti tidak berbeda nyata pada taraf kepercayaan 95\% (DMRT)

\section{Pertumbuhan diameter}

Perlakuan interval penyiraman yang mempengaruhi secara sangat nyata pertumbuhan diameter semai Mangium. Perlakuan inokulasi mikoriza dan asal sumber benih tidak mempengaruhi pertumbuhan diameter semai Mangium (Tabel 2). Secara umum inokulasi mikoriza meningkatkan pertumbuhan diameter semai Mangium sebesar 8,61\% dibandingkan semai tanpa inokulasi mikoriza. 


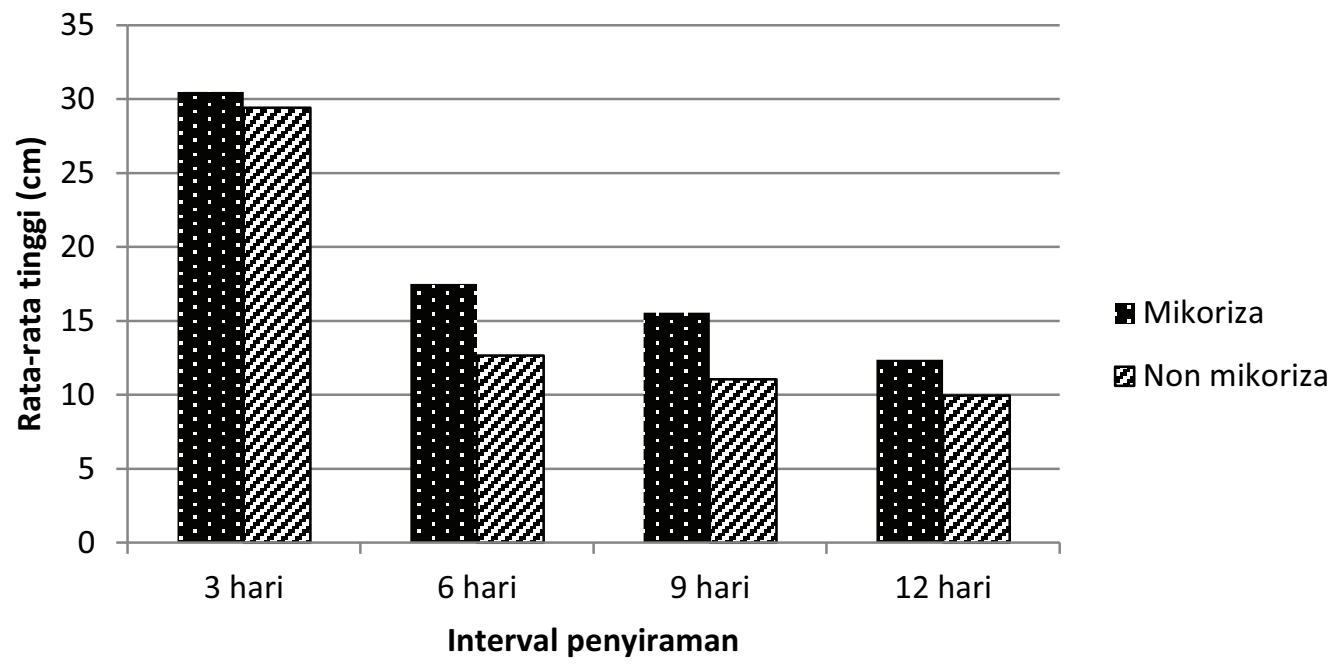

Gambar 3. Perbandingan rata-rata pertumbuhan tinggi semai Mangium umur 7 bulan pada berbagai taraf perlakuan interval penyiraman

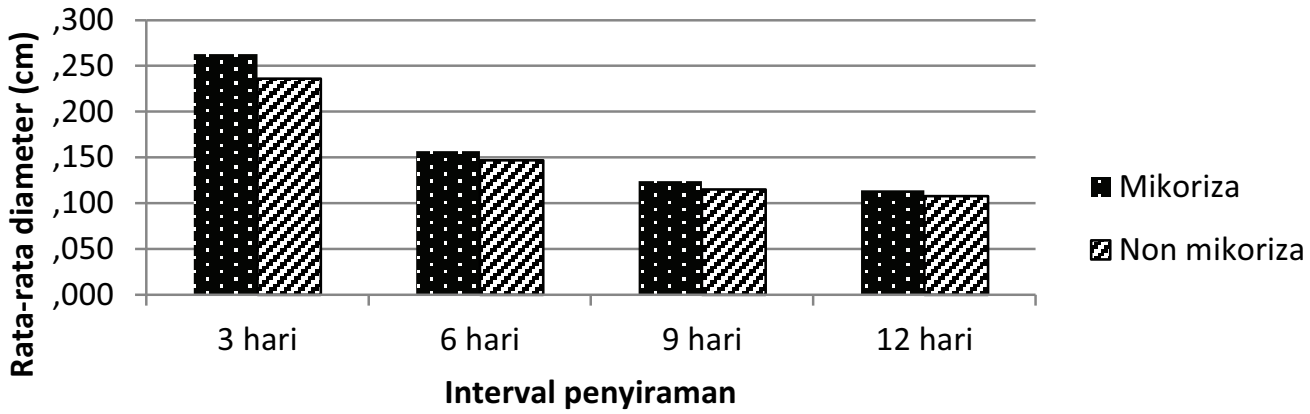

Gambar 4. Perbandingan rata-rata pertumbuhan diameter semai Mangium umur 7 bulan pada berbagai taraf perlakuan interval penyiraman

\section{Pertumbuhan biomassa total}

Perlakuan interval penyiraman berpengaruh secara sangat nyata pada pertumbuhan biomassa total semai mangium. Semai yang berasal dari kebun benih F-1 Wonogiri mempunyai rata-rata biomassa total paling tinggi diantara rata-rata biomassa total semai yang berasal dari kebun benih lainnya. Pada penelitian ini, secara umum inokulasi mikoriza meningkatkan ratarata pertumbuhan biomassa total semai Mangium sebesar $\quad 54,40 \%$ dibandingkan dengan semai Mangium tanpa inokulasi mikoriza (Tabel 2).

Rata-rata pertumbuhan tinggi, diameter dan biomassa total semai Mangium lebih besar pada semai Mangium yang bermikoriza, karena adanya simbosis mutualisme antara akar tanaman Mangium dengan VAM. Dari hasil penelitian Umar (2003) dilaporkan bahwa media bermikoriza meningkatkan pertumbuhan tinggi semai, berat kering total dan top-root ratio semai eboni di persemaian. 
Penyebabnya adalah mikoriza secara efektif dapat meningkatkan serapan unsur hara, baik unsur hara makro maupun mikro. Peranan penting mikoriza dalam pertumbuhan tanaman adalah kemampuannya untuk menyerap air dan unsur hara baik mikro maupun makro. Selain itu akar bermikoriza dapat menyerap unsur hara dalam bentuk terikat dan tidak tersedia bagi tanaman.
Jika suatu tanaman mengalami cekaman air yang semakin besar, diferensiasi organ-organ baru dan perluasan maupun pembesaran organ yang telah ada merupakan bagian yang pertama kali menunjukkan reaksi. Baon (2004) mengatakan bahwa inokulasi VAM menghasilkan reaksi tanaman yang positif terhadap tinggi tanaman, diameter batang, jumlah daun, luas daun tanaman kakao.

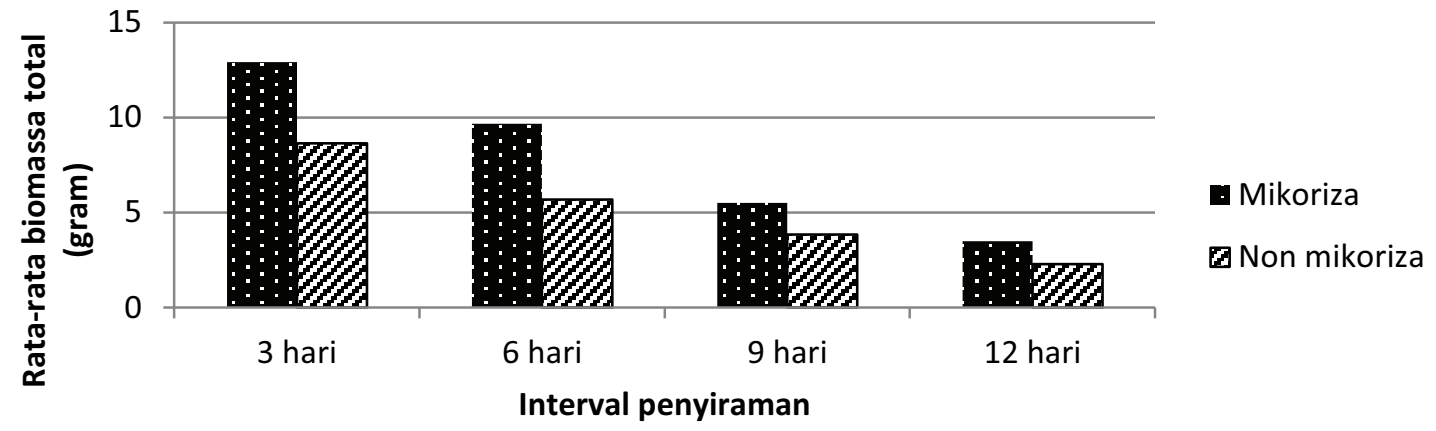

Gambar 5. Perbandingan rata-rata pertumbuhan biomassa total semai Mangium umur 7 bulan pada berbagai taraf perlakuan interval penyiraman

\section{Mekanisme adaptasi tanaman Mangium terhadap cekaman kekeringan}

Cekaman kekeringan pada tanaman disebabkan oleh kekurangan pasokan air di daerah perakaran dan permintaan air yang berlebihan oleh daun dalam kondisi laju evapotranspirasi melebihi laju absorbsi air oleh akar tanaman. Serapan air oleh akar tanaman dipengaruhi oleh laju transpirasi, sistem perakaran, dan ketersediaan air tanah (Lakitan, 1996).

\section{Status air jaringan tanaman}

Status air di dalam jaringan tanaman ditunjukkan oleh kadar air relatif daun tanaman. Inokulasi mikoriza meningkatkan kadar air relatif daun sebesar $12,64 \%$ dibandingkan semai tanpa inokulasi mikoriza (Tabel 3). Perlakuan interval penyiraman setiap 3 dan 6 hari berbeda nyata dalam mempengaruhi kadar air relatif daun semai Mangium, sedangkan perlakuan interval 
penyiraman setiap 9 hari tidak berbeda nyata dengan perlakuan interval penyiraman setiap 12 hari dalam mempengaruhi kadar air relatif daun tanaman. Semai Mangium yang berasal dari F-1 Wonogiri memberikan rata-rata kadar air daun tertinggi yaitu sebesar 79,91\% diikuti Grup A sebesar 79,29\%; Grup C sebesar 76,54\% dan rata-rata kadar air terendah berasal dari Grup B yaitu sebesar 74,09\%.

Tabel 3. Rata-rata kadar air relatif daun, luas daun spesifik dan nisbah pucuk akar semai Mangium umur 7 bulan dari 4 sumber benih terhadap perlakuan mikoriza dan interval penyiraman

\begin{tabular}{llcll}
\hline \multicolumn{1}{c}{ Perlakuan } & \multicolumn{1}{c}{ KAR } & LDS & \multicolumn{1}{c}{ Perlakuan } & \multicolumn{1}{c}{ NPA } \\
\hline Inokulasi mikoriza & $82,06 \mathrm{a}$ & $0,17 \mathrm{a}$ & Inokulasi mikoriza & $3,75 \mathrm{a}$ \\
Tanpa inokulasi mikoriza & $72,85 \mathrm{~b}$ & $0,15 \mathrm{~b}$ & Tanpa inokulasi mikoriza & $3,06 \mathrm{~b}$ \\
\hline Grup A & 79,29 & 0,16 & F-1 Wonogiri & $3,69 \mathrm{a}$ \\
Grup B & 74,09 & 0,16 & Grup A & $3,42 \mathrm{~b}$ \\
Grup C & 76,54 & 0,16 & Grup B & $3,31 \mathrm{~b}$ \\
F-1 Wonogiri & 79,91 & 0,17 & Grup C & $3,20 \mathrm{~b}$ \\
\hline Penyiraman setiap 3 hari & $89,22 \mathrm{a}$ & $0,21 \mathrm{a}$ & Penyiraman setiap 3 hari & $5,60 \mathrm{a}$ \\
Penyiraman setiap 6 hari & $80,18 \mathrm{~b}$ & $0,15 \mathrm{~b}$ & Penyiraman setiap 6 hari & $4,03 \mathrm{~b}$ \\
Penyiraman setiap 9 hari & $71,38 \mathrm{c}$ & $0,14 \mathrm{~b}$ & Penyiraman setiap 9 hari & $2,46 \mathrm{c}$ \\
Penyiraman setiap 12 hari & $69,05 \mathrm{c}$ & $0,13 \mathrm{~b}$ & Penyiraman setiap 12 hari & 1,54 \\
\hline
\end{tabular}

Keterangan: Angka-angka yang diikuti oleh satu atau lebih huruf yang sama berarti tidak berbeda nyata pada taraf kepercayaan 95\% (DMRT). KAR : KadarAir Relatif Daun, LDS : Luas Daun Spesifik, NPA : Nisbah Pucuk Akar

Persentase kadar air relatif daun yang lebih tinggi pada tanaman yang bermikoriza dibandingkan dengan tanaman yang tidak bermikoriza menunjukkan pasokan air ke daun tanaman oleh akar lebih baik pada tanaman yang bersimbiosis dengan mikoriza. Menurut Chakravarty dan Chatapaul (1988) dalam Sasli (2004), ketahanan tanaman bermikoriza ini disebabkan oleh peningkatan kemampuan tanaman untuk menghindari pengaruh langsung dari kekeringan dengan jalan meningkatkan penyerapan air melalui sistem gabungan akar dan mikoriza. Selain itu, hifa cendawan ternyata masih mampu untuk menyerap air dari pori-pori tanah pada saat akar tanaman sudah kesulitan mengasorbsi air. Tanaman dapat mengambil air relatif lebih banyak karena penyebaran hifa di dalam tanah juga sangat luas (Setiadi, 1989 dalam Sasli, 2004). Kemampuan mikoriza menyerap air dari pori-pori tanah dikarenakan hifa utama cendawan mikoriza di luar akar membentuk percabangan hifa yang lebih kecil dan lebih halus dari rambut akar dengan diameter kira-kira $2 \mu \mathrm{m}$.

\section{Penebalan daun}

Luas daun spesifik dapat digunakan untuk memperkirakan ketebalan daun, semakin rendah luas 
daun spesifik maka daun akan semakin tebal (Sitompul dan Guritno, 1995). Salah satu adaptasi tanaman terhadap cekaman kekeringan adalah menambah ketebalan daun karena akan semakin tebal lapisan kutikula yang dapat menghambat kehilangan air.

Hasil perbandingan rerata menunjukkan adanya penurunan luas daun spesifik dengan semakin meningkatnya perlakuan taraf interval penyiraman baik pada tanaman yang bersimbiosis dengan mikoriza maupun yang tidak (Tabel 3). Tanaman yang bersimbiosis dengan mikoriza mempunyai luas daun spesisik $11,76 \%$ lebih tinggi dibandingkan dengan tanaman tanpa mikoriza. Besarnya luas daun spesifik tanaman Mangium yang bermikoriza dibandingkan dengan yang tidak bermikorisa semakin menurun seiring dengan meningkatnya taraf perlakuan interval penyiraman.

Secara umum rata-rata luas daun spesifik pada tanaman yang bersimbiosis dengan mikoriza lebih tinggi dibandingkan dengan tanaman yang tidak bersimbiosis dengan mikoriza. Haryantini dan Santoso (2001) melaporkan bahwa pemberian VAM jenis Gigaspora margarita memberikan pengaruh pada beberapa komponen pertumbuhan cabai merah yang terlihat pada parameter luas daun spesifik, berat kering tajuk dan persentase pembentukan buah. Tumbuhan bereaksi terhadap kekurangan air dengan mengurangi laju transpirasi untuk penghematan air. Terjadinya kekurangan air pada daun akan menyebabkan sel-sel penjaga kehilangan turgornya. Kemampuan mengendalikan transpirasi merupakan salah satu mekanisme adaptasi tanaman terhadap adanya cekaman kekeringan (Pitono et al., 2008). Dilaporkan bahwa ukuran daun yang kecil dan sukulen mengurangi laju kehilangan air melalui tanspirasi (Farooq et al., 2009).

\section{Perkembangan perakaran}

Nisbah pucuk akar menunjukkan kemampuan tanaman menyerap air ketika terjadi cekaman kekeringan (Yoshida dan Hasegawa, 1982). Salah satu mekanisme adaptasi tanaman terhadap cekaman kekeringan untuk mempertahankan status air tetap tinggi adalah mengembangkan perakaran, sehingga meningkatkan kemampuan tanaman dalam mengabsorbsi air. Inokulasi mikoriza menaikkan rata-rata nisbah pucuk akar semai Mangium sebesar 22,84\% dibandingkan semai tanpa inokulasi mikoriza. Rata-rata nisbah pucuk akar pada semai Mangium akibat adanya 
perlakuan interval penyiraman memperlihatkan pola yang sama antara tanaman yang diinokulasi dengan mikoriza maupun yang tidak, yaitu mengalami penurunan seiring dengan meningkatnya perlakuan taraf interval penyiraman (Tabel 3).

Nisbah pucuk akar semai Mangium semakin menurun dengan semakin rendahnya kadar air pada media. Menurut Hale dan David (1987) peningkatan sistem perakaran umumnya diikuti dengan penurunan pertumbuhan tajuk. Tanaman yang lebih mengutamakan pertumbuhan akar daripada tajuknya mempunyai kemampuan lebih baik untuk bertahan pada kondisi kekeringan. Bila tanaman dihadapkan pada kondisi kering terdapat dua macam tanggapan yang dapat memperbaiki status air yaitu (1) tanaman mengubah sebaran asimilat baru untuk mendukung pertumbuhan akar dengan mengorbankan tajuk, sehingga dapat meningkatkan kapasitas akar menyerap air serta menghambat pemekaran daun untuk mengurangi transpirasi; (2) tanaman akan mengatur derajat pembukaan stomata untuk menghambat kehilangan air lewat transpirasi (Sinaga, 2008).

\section{Analisis kandungan unsur hara} pada daun
Daun dari semai tanaman Mangium pada akhir penelitian dianalisis kandungan unsur hara N,P dan K. Kadar unsur hara N lebih tinggi pada perlakuan inokulasi mikoriza dibandingkan dengan yang tanpa inokulasi mikoriza pada semua taraf perlakuan interval penyiraman (Gambar 6). Inokulasi mikoriza meningkatkan kadar unsur hara $\mathrm{N}$ sebesar 18,88\% dibandingkan dengan semai tanpa inokulasi mikoriza.

Tanaman yang diinokulasi mikoriza, kandungan unsur hara $\mathrm{P}$ relatif sama pada perlakuan interval penyiraman setiap 3 dan 6 hari, meningkat pada perlakuan interval penyiraman setiap 9 hari dan menurun pada perlakuan interval penyiraman setiap 12 hari (Gambar 7).

Secara umum inokulasi mikoriza meningkatkan rata-rata penyerapan kadar unsur $\mathrm{K}$ pada daun sebesar $8,8 \%$ dibandingkan semai Mangium tanpa mikoriza (Gambar 8). Kandungan unsur hara $\mathrm{K}$ menunjukkan kadar yang lebih tinggi pada perlakuan inokulasi mikoriza dibandingkan tanpa inokulasi mikoriza kecuali pada perlakuan interval penyiraman setiap 12 hari. Pada tanaman yang bermikoriza, jaringan hifa eksternal dari mikoriza akan memperluas bidang serapan air dan hara. Serapan air yang 
lebih besar oleh tanaman bermikoriza, juga membawa unsur hara yang mudah larut dan terbawa oleh aliran masa seperti $\mathrm{N}, \mathrm{K}$ dan $\mathrm{S}$, sehingga serapan unsur tersebut juga makin meningkat.

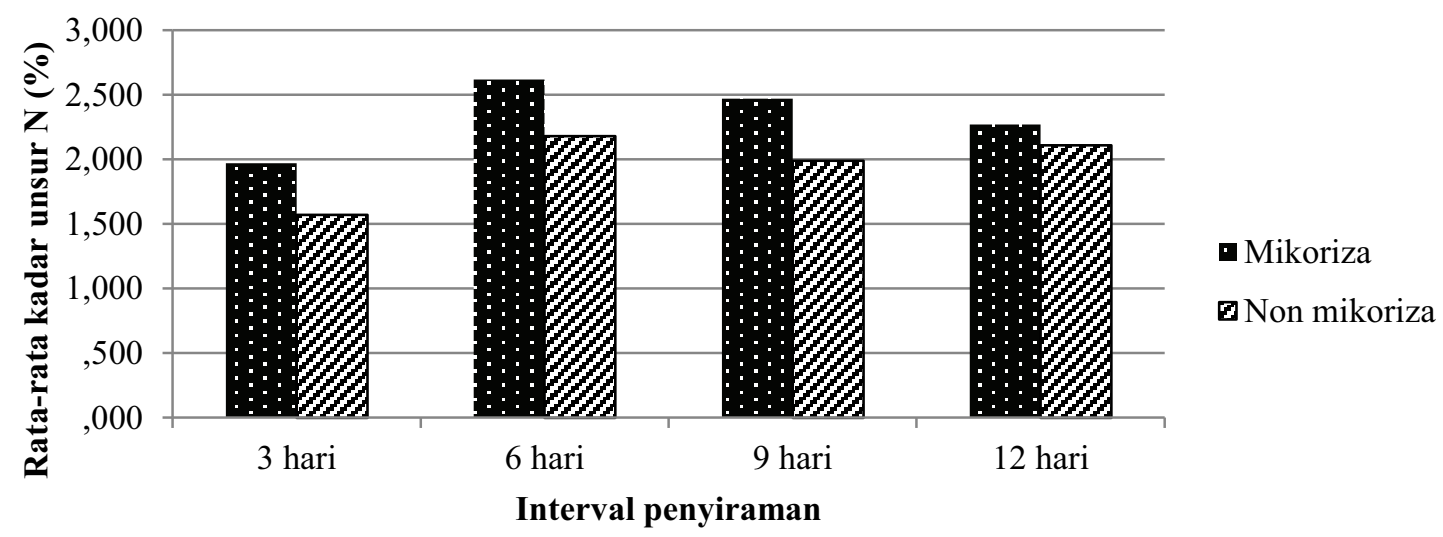

Gambar 6. Perbandingan rata-rata kadar unsur N pada daun semai Mangium pada berbagai taraf perlakuan cekaman kekeringan

Disamping serapan hara melalui aliran masa, serapan $\mathrm{P}$ yang tinggi juga disebabkan karena hifa cendawan juga mengeluarkan enzim phosphatase yang mampu melepaskan $\mathrm{P}$ dari ikatan-ikatan spesifik, sehingga tersedia bagi tanaman. Mikoriza menginfeksi akar tanaman kemudian memproduksi jalinan hifa secara intensif sehingga tanaman yang bermikoriza akan mampu meningkatkan kapasitasnya dalam penyerapan unsur hara. VAM meningkatkan kadar N,P dan K daun. Seperti diketahui bahwa daun merupakan tempat berlangsungnya fotosintesis. Proses fotosintesis dipengaruhi oleh $\mathrm{CO}_{2}$ dan $\mathrm{O}_{2}$ di udara, temperatur, cahaya, air tanah, klorofil dan hara $(\mathrm{N}, \mathrm{P}, \mathrm{K}, \mathrm{Fe}$ dan $\mathrm{Mg})$.
Tanaman bermikoriza meningkatkan kadar N,P,K, bobot kering dan fotosintesis (Salisbury dan Ross, 1995).

\section{Reaksi tanaman Mangium yang mengalami cekaman kekeringan}

Secara umum semai Mangium yang mengalami kekeringan menunjukkan perubahan baik pada pertumbuhannya maupun pada fisiologis tanamannya. Semakin bertambah umur tanaman, kekeringan semakin nyata menekan pertumbuhan yang ditunjukkan semakin rendah hasilnya (tinggi, diameter dan biomassa total semai) Perlambatan pertumbuhan terus terjadi seiring dengan semakin tinggi tingkat perlakuan interval penyiraman (sampai pada perlakuan interval penyiraman 
setiap 12 hari). Pertumbuhan tanaman pada dasarnya disebabkan oleh pembesaran sel (cell enlargement) dan pembelahan sel (cell division). Fungsi air bagi tanaman adalah menjaga turgiditas yang penting bagi perbesaran sel dan pertumbuhan. Kekurangan air dalam jumlah yang besar menyebabkan kurangnya tekanan turgor pada/dalam pertumbuhan tumbuhan vegetative (Kramer, 1980).

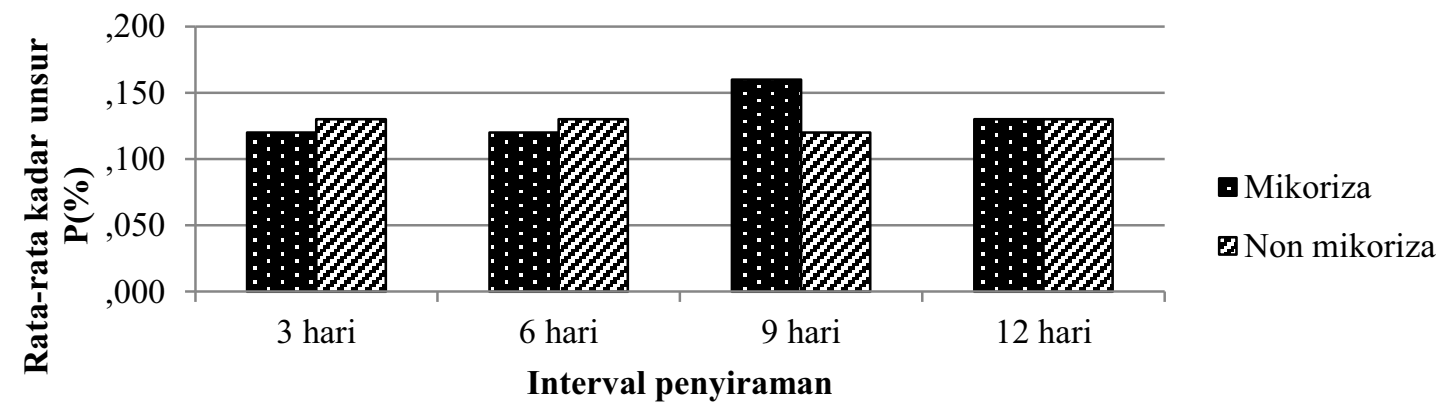

Gambar 7. Perbandingan rata-rata kadar unsur P pada daun semai Mangium pada berbagai taraf perlakuan interval penyiraman

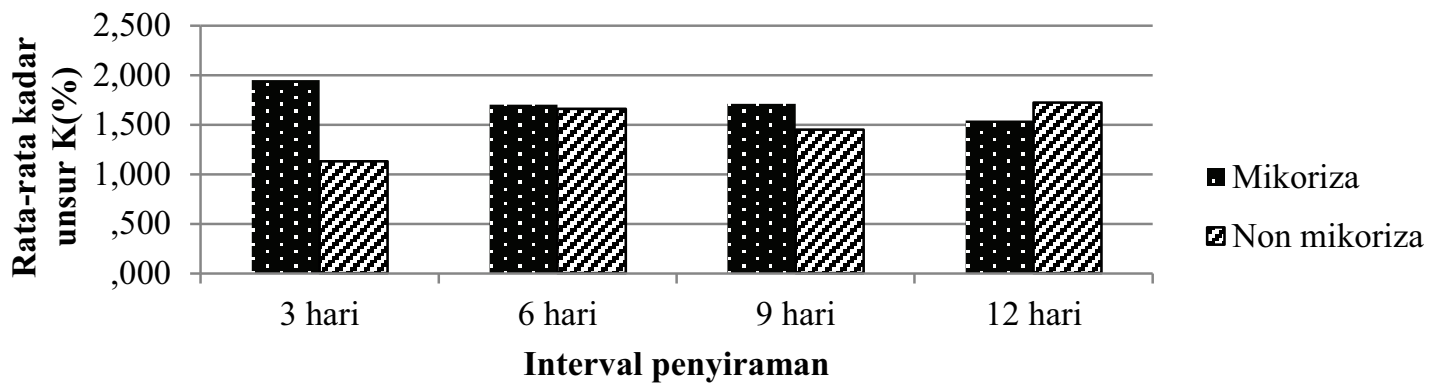

Gambar 8. Perbandingan rata-rata kadar unsur K pada daun semai Mangium pada berbagai taraf perlakuan interval penyiraman

Secara visual semai Mangium yang mengalami cekaman kekeringan (perlakuan penyiraman setiap 9 dan 12 hari) menunjukkan perubahan seperti tinggi tanaman yang lebih rendah dibandingkan dengan tanaman yang tidak mengalami cekaman kekeringan (perlakuan setiap 3 hari penyiraman), warna daun hijau gelap, sebagian menggulung dan lebih tebal (perlakuan penyiraman setiap 9 dan 12 hari), layu pada tajuk bagian atas serta rontok pada daun-daun bagian bawah (perlakuan penyiraman setiap 12 hari) (Gambar 9). 

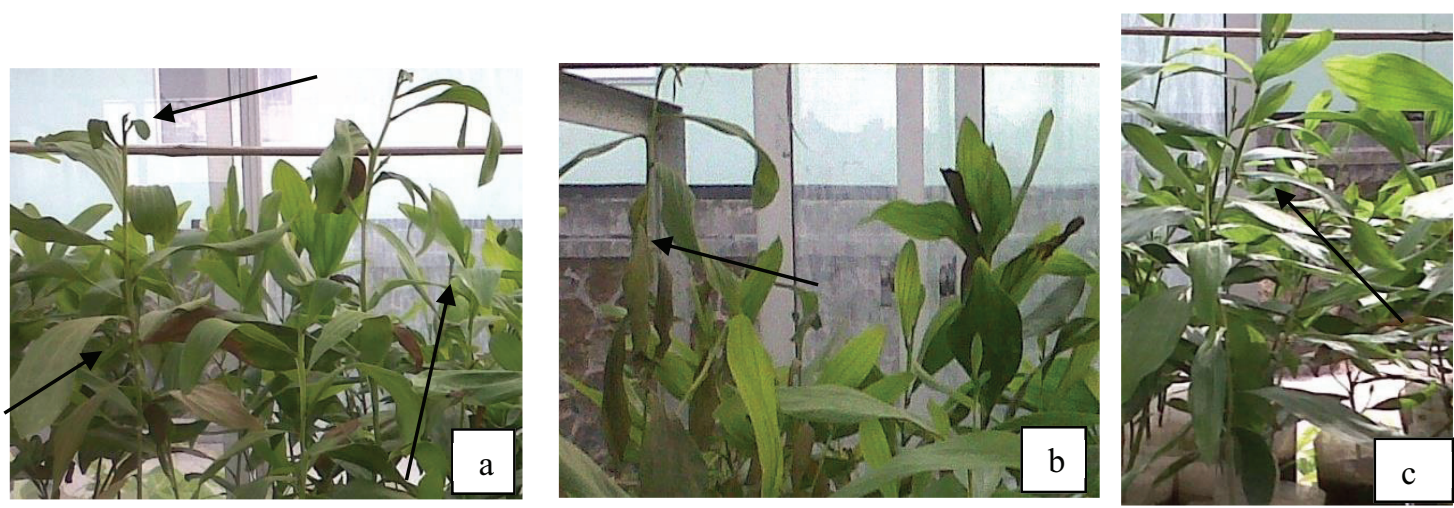

Gambar 9. Semai Mangium pada kondisi tercekam kekeringan (a) daun kering sebagian menggulung (b) tajuk mengalami kelayuan (c) daun normal tanpa kelayuan

Penurunan hasil pada semua peubah ketika diberikan cekaman kekeringan menunjukkan bahwa tanaman berusaha untuk menghindari cekaman kekeringan agar dapat bertahan hidup dan melangsungkan metabolisme, sehingga dapat tumbuh. Fukai dan Coeper (1995) serta Mitra (2001) menjelaskan bahwa dehydration avoidance merupakan kemampuan tanaman untuk memelihara potensial air jaringan tetap tinggi meskipun pada kondisi kurang air, dengan cara memperbaiki serapan air dengan meningkatkan kedalaman akar, menyimpannya dalam sel tanaman, dan mengurangi hilangnya air dengan mengurangi jerapan panas melalui pengurangan luas daun. Dikatakan oleh Taiz dan Zeiger (2002) bahwa cekaman kekeringan menyebabkan penurunan turgor sel yang berakibat pada menurunnya luas daun karena daun tua cepat mengalami penuaan akhirnya gugur sedangkan daun yang baru terbentuk akan berukuran lebih kecil.

\section{KESIMPULAN}

Taraf perlakuan interval penyiraman yang semakin tinggi menyebabkan semakin rendah kadar air pada media sehingga menyebabkan penurunan pertumbuhan tinggi, diameter dan biomassa total semai Mangium. Mekanisme adaptasi semai Mangium terhadap kondisi kekeringan dilakukan dengan penurunan kadar air relatif daun, nisbah tajuk akar dan penurunan luas daun spesifik. Mikoriza meningkatkan pertumbuhan tinggi sebesar 20,35\%, diameter sebesar $8,61 \%$ dan biomassa total semai Mangium sebesar 54,20\% melalui perannya dalam penyerapan air dan unsur-unsur hara dari dalam tanah.

Sumber benih mempengaruhi pertumbuhan biomassa total semai Mangium, tetapi tidak mempengaruhi tinggi dan diameter semai Mangium 
umur 7 bulan. Biomassa total tertinggi berasal dari F-1 Wonogiri $(7,14$ gram); Grup B (6,82 gram); Grup C (6,21 gram) dan Grup A (5,84 gram).

Dalam pengembangan tanaman Mangium sebagai salah satu jenis tanaman dalam rehabilitasi lahan kritis, sebaiknya menggunakan benih yang berasal dari F-1 Wonogiri yang mempunyai pertumbuhan biomassa paling tinggi diantara Grup B, Grup C dan Grup A. Perlu dilakukan penelitian dengan menggunakan bibit Mangium yang berasal dari sumber benih yang lebih mewakili kondisi tapak yang mengalami kekeringan dengan taraf perlakuan interval penyiraman yang lebih panjang.

\section{UCAPAN TERIMA KASIH}

Penelitian ini dilakukan dengan dana DIPA Balai Besar Penelitian Bioteknologi dan pemuliaan Tanaman Hutan Yogyakarta. Penulis mengucapkan terima kasih kepada Tim Akasia Balai Besar Penelitian Bioteknologi dan pemuliaan Tanaman Hutan dan semua pihak yang telah membantu dalam pelaksanaan penelitian dan penyediaan referensi dalam penulisan naskah.

\section{DAFTAR PUSTAKA}

Auge, R. M. (2001). Water Relations, Drought, and Vesicular Arbuscular
Mycorrhizal Symbiosis. Journal of Mycorrhiza, 11, 3-42.

Baon, J. B. (2004). Peranan Jamur Mikoriza pada Tanah Agrisol dalam Meningkatkan Pertumbuhan Tanaman Kakao. Jurnal Agrivita, 19(3), 123124.

Bray, E. A. (1997). Plant Responses to Water Deficit. Journal of Trend Plant Science, 21, 48-54.

Brundrett, M., Boucher, N., Dell, N. B., Grove, T., \& Malajczuk, N. (1994). Working with Mycorrhizas in Forestry and Agriculture. In International Mycorrhizal Workshop. Kaiping, China.

Brundrett, M., Beeger, Dell, B., Groove, T., \& Malajzuk, N. (1996). Working with Mycorrhizas in Forestry and Agriculture. ACIAR Monograph, 32, 374.

Chakravarty, P., \& Chatapaul, M. (1988). Mycorrhizal and Control of Root Diseases. Abstract Pubishers Eroupean Sump on Mycorrhizal, 51 p. Chechoslovakia.

Cooke, M.A., Widden, P., \& O'Halloran, I.P. (1993). Development of VesicularArbuscular Mycorrhizae in Sugar Maple (Acer saccharum) and Effects of Base-Cation Ammendment on Vesicle and Arbuscule Formation. The Canadian Journal of Botany, 71, 1421-1426.

Farooq, M., Wahid, A., Kobayashi, N., Fujita, D., \& Basra, S. M. A. (2009). Plant Drought Stress: effects, mechanisms, and management. Journal of Agronomy Sustainable Development, 29, 185-212.

Fukai, S., \& Coeper, M. (1995). Development of Drought Resistant Cultivars using Physio- Morphological Traits in Rice. Field Crops Research, 40, 67-86.

Gunawan, A. W. (1993). Mikoriza Arbuskula. Pusat Antar Universitas Ilmu Hayati. Bogor: IPB.

Hale, M.G., \& David, M. O. (1987). Physiology of Plant under Stress. New York: John Wiley and Sons.

Haryantini, B. A., \& Santoso, M. (2001). Pertumbuhan dan Hasil Cabai Merah pada Andisol yang Diberi Mikoriza, 
Pupuk Fosfor dan Zat Pengatur Tumbuh. Biosains, 1(3), 50-57.

Kramer, P. J. (1980). Plant and Soil Water Relationship. A Modern Synthesis. New York: Tata Mc Graw-Hill Publ. Co. Ltd.

Lakitan, B. (1996). Fisiologi Pertumbuhan dan Perkembangan Tanaman. Jakarta: Rajawali Pers.

Levitt, J. (1980). Responses of Plants to Environmental Stresses: Vol II. Water, Radiation, Salt, and other Stresses. New York Academic Press.

Mitra, J. (2001). Genetics and Improvement of Drought Resistance in Crop Plants. Current Science, 80, 758-762.

Moose, B. (1981). Vesicular Arbuscular Mycorhiza Research for Tropical Agricultural. Hawai Institute of Tropical Agriculture and Human Resources. University of Hawaii. Research Bulletin, 194.

O’Connor, P. J., Smith, S. E., \& Smith, F. A. (2001). Arbuscular Mycorrhizal Associations in the Southern Simpson Desert. Australian Journal of Botany, 49, 493-499.

Pitono, J., Nurhayati, H., \& Setiawan. (2008). Seleksi Ketahanan Terhadap Stress Kekeringan Pada Tiga Nomor Somaklon Nilam di Lapangan pp. 201-212. (tidak dipublikasikan). Laporan Teknis Penelitian TA. 2008. Balittro.

Salisbury, F. B., \& Ross, C. W. (1995). Fisiologi Tumbuhan: Jilid II. Bandung: ITB.

Sasli, I. (2004). Peranan Mikorisa Vesikula Arbuskula (MVA) Dalam Peningkatan Resistensi Tanaman Terhadap Cekaman Kekeringan. Sekolah Pasca Sarjana. Institut Pertanian Bogor.

Sitompul, S. M., \& Guritno, B. (1995). Analisis Pertumbuhan Tanaman. Yogyakarta: Gadjah Mada University Press.

Suhardi (1989). Mikorisa Arbuskula (MVA). Pedoman Kuliah. Yogyakarta: PAU Bioteknologi, Universitas Gadjah Mada.

Taiz, L., \& Zeiger, E. (2002). Plant Physiology. (3rd ed). Sunderland, Massachusetts: Sinauer Associates, Inc. Publishers.
Umar, H. (2003). Pengaruh Media Bermikoriza dan Pupuk Rock Phosfate Terhadap Pertumbuhan Semai Eboni. Jurnal Agroland, 10 (3), 254-258.

Yoshida, S., \& Hasegawa, S. (1982). The Rice Root System: Its Development and Function. In M. Tahane (Ed.), Drought Resistance Crops With Emphasis on Rice (pp. 97-114). Los Banos, Philippine: IRRI. 
Jurnal Pemuliaan Tanaman Hutan

Vol 9 No. 1, Juli 2015, 13 - 29 